Peningkatan Kemampuan Pemecahan Masalah Melalui Model Pembelajaran Berbasis Masalah pada Siswa Kelas XI-IPA SMAN I Sinjai Tengah (Materi Pokok Laju Reaksi)

\title{
Peningkatan Kemampuan Pemecahan Masalah Melalui Model Pembelajaran Berbasis Masalah pada Siswa Kelas XI-IPA SMAN 1 Sinjai Tengah (Materi Pokok Laju Reaksi)
}

\author{
Improvemant of Problem Solving Competence through problem-based \\ Learning Model of Grade XI of Science Students at SMAN 7 Central Sinjai
}

\author{
Irsyam \\ UPT SMAN 7 Sinjai \\ Email: irsyam680528@gmail.com
}

\begin{abstract}
ABSTRAK
Jenis penelitian ini adalah penelitian tindakan kelas (classroom action research) yang terdiri atas dua siklus dengan pendekatan deskriptif kualitatif. Subjek dalam penelitian ini adalah siswa klas XI-MIPA SMAN 7 Kabupaten Sinjai sejumlah tiga puluh tiga orang. Data tentang aktivitas siswa dan aktivitas guru dikumpulkan dengan lembar lembar instrumen observasi, dan data mengenai respon siswa tentang pembelajaran berbasis masalah menggunakan angket. Data tersebut dianalisis dengan menggunakan teknik analais data kualitatif. Hasil penelitian menunjukkan bahwa (1) pembelajaran kimia melalui model pembelajaran berbasis masalah, dapat meningkatkan kemampuan pemecahan masalah, hingga mencapai atau melampaui KKM, (2) pembelajaran kimia melalui pendekatan pemecahan masalah dengan menerapkan model pembelajaran berbasis masalah, dapat meningkatkan kualitas proses belajar kimia siswa yang ditunjukkan oleh aktivitas siswa mencapai kriteria ideal, (4) respon siswa terhadap kegiatan pembelajaran yang dialaminya mencapai rata-rata $92,42 \%$.
\end{abstract}

Kata Kunci: pemecahan masalah, pembelajaran berbasis masalah

\begin{abstract}
The study is a classroom action research which consists of two cycles with descriptive qualitative approach. The subjects of the study were 33 students of grade XI of Science at SMAN 1 of Central Sinjai in Sinjai District. Data on students and tearchers'activities were collected by using observation sheet instrument and data on students' responses conserning problem-based learning were collected by employing questionnaire. Those data were analyzed by employing qualitative data analyisis teacnique.The results of the study reveal that (1) learning Chemistry through problembased learning model can improve problem solving competence and achieve or pass sthe KKM, (2) learning Chemistry through problem solving approach by applying problem-based learning model can improve students' quality in learning Chemistry shown by students' activities which achieved the ideal criteria, (4) students' responses on learning activities achieved $92,42 \%$ in average.
\end{abstract}


Peningkatan Kemampuan Pemecahan Masalah Melalui Model Pembelajaran Berbasis Masalah pada Siswa Kelas XI-IPA SMAN I Sinjai Tengah (Materi Pokok Laju Reaksi)

Keywords: problem based, problen-based learning

\section{PENDAHULUAN}

Seiring
berkembangnya zaman, pendidkan selalu berubah. Perubahan tersebut tidak hanya berorientasi pada masa lalu dan masa kini, tetapi merupakan proses yang mengantisipasi dan membicarakan masa depan dan pelaksanaannya harus dipikirkan apa yang akan dihadapi peserta didik di masa yang akan datang. Pendidikan yang ideal adalah pendidikan yang tidak hanya mempersiapkan para siswanya untuk suatu profesi atau jabatan, tetapi juga untuk menyelesaikan masalah-masalah yang dihadapinya dalam kehidupan seharihari.

Pendidikan merupakan salah satu faktor penunjang yang sangat penting bagi perkembangan perubahan peradaban manusia dalam suatu bangsa. Bangsa yang mempunyai peradaban maju adalah bangsa yang mempunyai sumber daya manusia yang berkualitas. Dalam persaingan global, bangsa Indonesia sebagai bangsa yang berdaulat perlu berpacu untuk terus mengembangkan dan meningkatkan kualitas sumber daya manusia sehingga dapat diperhitungkan dimata dunia. Oleh karena itu, peningkatan kualitas sumber sumber daya manusia merupakan kewajiban yang harus dilakukan secara terencana, terarah, intensif, efektif, dan efisien dalam proses pembangunan, kalau tidak ingin bangsa ini kalah dalam menjalani era globalisasi tersebut (Tilaar, 2002:2).

Kualitas pendidikan tidak hanya ditentukan oleh sistem pendidikan akan tetapi ditentukan oleh kualitas guru, model serta metode pembelajaran yang digunakan. Guru dalam menyajikan materi pelajaran bukan hanya fokus pada materi saja, melainkan membantu siswa untuk berinteraksi dengan berbagai sumber belajar dalam mendapatkan pengetahuan, keahlian, dan keterampilan serta sikap yang menuju kepada perubahan tingkah laku baik secara kognitif, efektif maupun secara psikomotorik.

Dalam proses tersebut diperlukan guru yang memberikan keteladanan, membangun kemauan, dan mengembangkan potensi dan kreativitas peserta didik. Implikasinya adalah pergeseran paradigma proses pendidikan, yaitu dari paradigma pengajaran ke paradigma pembelajaran. Pembelajaran merupakan aspek kegiatan manusia yang kompleks yang tidak sepenuhnya dapat dijelaskan. Pembelajaran secara sederhana dapat diartikan sebagai produk interaksi berkelanjutan antara pengembangan dan pengalaman hidup. Dalam makna yang lebih kompleks pembelajaran hakekatnya adalah usaha sadar dari seseorang guru untuk membelajarkan siswanya untuk mencapai tujuan yang diharapkan. Secara implisit, jelas terlihat bahwa pembelajaran merupakan interaksi dua arah dari seorang guru dan siswa, di mana keduanya terjadi komunikasi yang intens dan terarah menuju pada suatu target yang telah ditetapkan sebelumnya.

Pergeseran paradigma proses pendidikan dari pengajaran ke 
Peningkatan Kemampuan Pemecahan Masalah Melalui Model Pembelajaran Berbasis Masalah pada Siswa Kelas XI-IPA SMAN I Sinjai Tengah (Materi Pokok Laju Reaksi)

pembelajaran telah memberi tantangan baru bagi guru dalam melaksanakan tugasnya di kelas. Peserta didik yang akan difasilitasi untuk dapat mencapai hasil belajar atau kompetensi yang diharapkan tidak semuanya memiliki karakteristik dan kemampuan yang sama. Demikian pula bahwa, tidak semua unsur penunjang belajar tiap sekolah sama. Hal tersebut menjadi hambatan belajar bagi siswa jika tidak diatasi secara tepat. Tindakan yang dapat dilakukan untuk mengatasinya adalah menggunakan berbagai pendekatan, metode, media dan sarana pendukung lainnya yang disesuaikan dengan jenis dan sifat hambatan belajar yang dihadapi oleh peserta didik.

Aktivitas belajar mengajar yang berlangsung dalam kelas dikendalikan dan dikontrol langsung oleh guru. Oleh sebab itu maka guru dituntut untuk lebih kreatif mengamati berbagai persoalan yang terjadi saat proses berlangsung. Berdasarkan hasil pengamatan tersebut diharapkan guru akan mampu melakukan berbagai inovasi pembelajaran, baik berupa pendekatan maupun metode, media atau hal lain yang dapat diterapkan saat mengajar sesuai dengan karakteristik bahan ajar serta kondisi siswa yang diajar.

Mata pelajaran kimia seperti halnya pelajaran lainnya memiliki karakteristik tertentu. Ilmu kimia merupakan pengetahuan teoritis tentang materi yang kebenarannya dapat dijelaskan dengan logika matematika. Sebagian aspeknya bersifat kasat mata yang dapat dibuat fakta kongkritnya dan sebagian aspek yang lain bersifat abstrak akan tetapi kebenarannya tetap dapat dibuktikan dengan logika matematika sehingga rasionalitasnya dapat dirumuskan atau diformulasikan. Karakteristik ini harus dipahami oleh guru kimia sebagai dasar untuk menyusun strategi pembelajarannya. Dengan mempelajari karakteristik setiap materi/konsep yang akan diajarkan oleh seorang guru kimia, maka diharapkan dapat memilih model, pendekatan, dan metode yang sesuai serta mengembangkan berbagai media pembelajaran yang dapat memudahkan siswa untuk memahaminya.

Pembelajaran kimia bertujuan memperoleh pemahaman tentang fakta dan konsep kimia, kemampuan mengenal dan memecahkan masalah, mempunyai keterampilan dan penggunaan laboratorium, serta mempunyai sikap ilmiah yang dapat dikembangkan dalam kehidupan sehari-hari. Tujuan pembelajaran kimia dapat dicapai oleh siswa melalui penerapan beberapa pendekatan, antara lain pendekatan pemecahan masalah, pendekatan induktif, inkuiri ilmia serta kontekstual. Pemecahan masalah sebagai suatu usaha mencari jalan keluar dari kesulitan guna mencapai suatu tujuan yang tidak begitu mudah segera dapat dicapai (Upu, 2003:31).

Dengan mempelajari karakteristik setiap materi atau konsep yang akan diajarkan oleh seorang guru, maka diharapkan dapat memilih model, pendekatan, dan metode yang sesuai serta mengembangkan berbagai media pembelajaran yang dapat memudahkan siswa untuk memahaminya. Kenyataan dilapangan menunjukkan bahwa pada umumnya siswa kelas XI-IPA SMA 
Peningkatan Kemampuan Pemecahan Masalah Melalui Model Pembelajaran Berbasis Masalah pada Siswa Kelas XI-IPA SMAN I Sinjai Tengah (Materi Pokok Laju Reaksi)

Negeri 7 Sinjai memilki kemampuan pemecah masalah (problem solving) yang rendah, ini dapat dilihat ketika siswa diberi masalah siswa cenderung pasif hanya menunggu penyelesaian dari guru, tidak memiliki upaya bagaimana langkah-langkah yang harus di tempuh dalam menyelesaikan masalah yang dihadapi. Berbagai Upaya yang telah dilakukan guru antara lain adalah menunjuk salah satu siswa yang bertindak sebagai tutor sebaya pada setiap kelompok kecil dalam proses pembelajaran, namun upaya tersebut belum berhasil. Salah satu upaya yang dapat ditempuh adalah dengan menerapkan model yang tepat dan sesuai dengan kompleksitas materi dan karakteristik siswa yang diajar. Salah satu model yang mampu meningkatkan keterlibatan siswa secara aktif dalam proses pembelajaran, yang akhirnya berpengaruh terhadap kemampuan memecahkan masalah adalah model berbasis masalah (problem solving model). Dasar pertimbangannya adalah model ini berangkat dari masalah-masalah aktual yang ada di lingkungan sekitar serta dapat mengakomodasi semua tingkatan berpikir yang ada dalam taxonomi Bloom.

Untuk meningkatkan kemampuan pemecahan masalah khususnya melalui pembelajaran berbasis masalah siswa diharapkan memiliki: (1) kemampuan mengedentifikasi masalah secara tertulis, (2) kemampuan merencanakan menyelesaikan masalah, kemampuan melaksanakan penyelesaian masalah, dan (4) kemampuan merefleksikan kembali penyelesaian. Dalam Peraturan Pemerintah No. 22 Tahun 2006, model pembelajaran berbasis masalah merupakan fokus dalam pembelajaran kimia yang mencakup masalah tertutup dengan solusi tunggal, masalah terbuka dengan solusi tidak tunggal dan masalah dengan berbagai cara penyelesaian. Untuk meningkatkan kemampuan pemecahan masalah perlu dikembangkan keterampilan memahami masalah, menyelesaikan masalah dan menafsirkan solusinya (Permen Diknas:2006).

Peneliti terdahulu

memperlihatkan bahwa dengan menerapakan model pembelajaran berbasis masalah dapat meningkatkan kemampuan pemecahan masalah dengan rata-rata hasil belajar meningkat dari 74,24 menjadi 82,73 dan siswa menjadi lebih aktif dalam proses pembelajaran (Darwis 2010).

Berdasarkan uraian di atas, maka kemampuan pemecahan masalah sangat penting dimiliki oleh peserta didik dan ini diharapkan dapat menunjang proses belajar siswa. Pemecahan masalah dapat melatih siswa memecahkan masalah sehingga pada akhirnya siswa dengan mudah dapat menyelesaikan masalah yang dihadapinya dan hal ini jelas berkaitan dengan pembelajaran berbasis masalah dimana siswa merasa tertantang, karena itu pula siswa akan lebih bersemangat untuk belajar. Beranjak dari hal itu, penulis merasa tertarik melakukan penelitian mengenai peningkatan kemampuan pemecahan masalah melalui pembelajaran berbasis masalah. 
Peningkatan Kemampuan Pemecahan Masalah Melalui Model Pembelajaran Berbasis Masalah pada Siswa Kelas XI-IPA SMAN I Sinjai Tengah (Materi Pokok Laju Reaksi)

\section{METODE PENELITIAN}

Penelitian ini merupakan penelitian tindakan kelas (Classroom ActionResearch) berupa pembelajaran berbasis masalah. Sesuai dengan hakekat penelitian tindakan kelas, maka prosedur pelaksanaan penelitian untuk masing-masing siklus melalui tahapantahapan; perencanaan (planning), pelaksanaan tindakan (Acting), observasi (observation) dan evaluasi (evaluating), refleksi( reflecting).

Penelitian ini dilaksanakan di SMAN 7 Sinjai Kelurahan Samaenre, Kecamatan Sinjai Tengah berjarak 15 Km dari Ibu Kota Kabupaten Sinjai, Provinsi Sulawesi Selatan.

Subjek penelitian adalah siswa kelas XI-IPA SMAN 7 Sinjai, Kelurahan Samaenre, Kecamatan Sinjai Tengah Provinsi Sulawesi Selatan, Tahun pelajaran 2018/2019, sebanyak 33 orang.

Instrumen merupakan alat yang digunakan oleh guru atau peneliti untuk memperoleh data tentang kemampuan kemampuan pemecahan masalah melalui model pembelajaran berbasis masalah. Jenis instrumen yang digunakan, yaitu:

1.Lembar observasi

2.Tes Kemampuan Pemecahan Masalah

3.Angket respon siswa

Sebelum instrument tersebut diujicobakan, terlebih dahulu dinyatakan bahwa instrument tersebut telah memenuhi syarat oleh para validator, baik validitas isi (content validity) dan validitas muka (face validity). Setelah divalidasi oleh validator dilakukan revisi atau perbaikan sesuai dengan arahan dan saran-saran validator.

Untuk menjawab pertanyaan penelitian yang diajukan, maka data yang diperoleh dianalisis dengan analisis deskriptif. Ada dua jenisdatayang diperolehdalam penelitian ini yaitu data kualitatif dan data kuantitatif.Datakualitatif berkaitan dengan proses yaitu aktifitas mengajar guru dan aktifitas belajar siswa, sedangkan data kuantitatif berkaitan dengan hasil berupa kemampuan pemecahan masalah dan respon siswa. Data kualitatif akan dianalisis dengan teknik analisis naratif berupa narasi atau uraian-uraian, sedangkan data kuantitatif akan dianalisis dengan teknik analisis statistik deskriptif.

\section{HASIL DAN PEMBAHASAN}

Kegiatan pembelajaran sebagai suatu alternatif dalam peningkatan hasil belajar perlu diupayakan agar lebih bermakna bagi siswa. Belajar bukan hanya sekedar mendengarkan dan mencatat saja. Namun proses belajar memerlukan keterlibatan aktivitas jasmani dan rokhani, fisik dan mental untuk bereksperimen atau demonstrasi sehingga meningkatkan partisipasi aktif siswa untuk menyelesaikan masalah yang diperoleh. Pembelajaran dengan pendekatan pemecahan masalah dapat membuat siswa lebih aktif dan kreatif dalam kegiatan pembelajaran, serta menambah pehaman siswa terhadap suatu konsep karena siswa belajar 
Peningkatan Kemampuan Pemecahan Masalah Melalui Model Pembelajaran Berbasis Masalah pada Siswa Kelas XI-IPA SMAN I Sinjai Tengah (Materi Pokok Laju Reaksi)

dengan cara membangun sendiri pengetahuannya.

Setelah

perencanaan, melakukan pengamatan, dan refleksi, selama silkus I dan II terhadap siswa kelas XI-IPA SMAN 7 Sinjai, hasil penelitian menunjukkan bahwa sudah mulai ada peningkatan kemampuan pemecahan masalah kimia menurut langkahlangkah polya serta peningkatan motivasi dan aktivitas dalam proses pembelajaran. Adapun analisis hsil penelitian pada siklus I dan II ditunjukkan pada Tabel 1 berikut.

Tabel 1. Analisis Hasil Penelitian pada Siklus I dan Siklus II

\begin{abstract}
1. Pada siklus I, perencanaan yang disusun belum semuanya terlaksana dengan baik, dan belum mengungkapkan rumusan masalah penelitian

2. Penerapan pendekatan pembelajaran berbasis masalah belum menujukkan hasil yang memuaskan

3. Hasil angket guru yang diperiksa oleh observer menunjukkan bahawa guru termasuk daik dalam mengelola pembelajaran dan aktivitas siswa tinggi

4. Guru kesulitan mencatat hal-hal yang terjadi saat pelaksanaan observasi karena memotivasi siswa lebih dikedepankan
\end{abstract}

5. Masih ada siswa yang belum termotivasi dengan baik, hal ini terlihat masih adanya kesalahan yang dilakukan siswa pada saat menyelesaikan soalsoal masalah kimia dengan mengikuti langkahlangkah Polya seperti dalam LKS.

6. Kemampuan pemecahan masalah kimia dengan mengikuti langkah-langkah Polya masih terbatas pada pemecahan masalah, perencanaan pemecahan masalah, dan pelaksanaan pemecahan masalah, untuk mengecek kembali proses dan hasil masih terkendala

7. Tes kemampuan pemecahan masalah kimia siswa hanya mempunyai nilai rata-rata 79,76

\section{Analisis Siklus II}

1. Pada siklus I, perencanaan yang disusun semuanya terlaksana dengan baik, dan telah mengungkapkan rumusan masalah penelitian

2. Penerapan pendekatan pembelajaran berbasis masalah menunjukkan hasil yang memuaskan

3. Hasil angket siswa menunjukkan bahwa minat siswa dalam mengikuti pembelajaran sangat antusias

4. Dengan bantuan guru minta (kolaborator) maka peneliti dapat terbantu untuk memgamati aktivitas siswa selama proses pembelajaran berlangsung

5. Hampir semua siswa telah termotivasi untuk menyelesaikan soal-soal pemecahan masalah dengan mengikuti langkah-langkah Polya seoerti dalam LKS

6. Hampir semua siswa telah mampu memecahkan masalah kimia dengan mengikuti langkah-langkah Polya, yaitu: pemahaman masalah, perencanaan pemecahan masalah, pelaksanaan perencanaan, dan mengecek kembali proses dan hasil.

7. Tes kemampuan pemecahan masalah kimia siswa mempunyai nilai rata-rata 85.90 berarti ada peningkatan dari siklus I 
Peningkatan Kemampuan Pemecahan Masalah Melalui Model Pembelajaran Berbasis Masalah pada Siswa Kelas XI-IPA SMAN I Sinjai Tengah (Materi Pokok Laju Reaksi)

Dari analisis data kedua siklus diatas, ternyata kemampuan siswa dalam memecahkan masalah kimia dapat tumbuh dan berkembang serta meningkatkan motivasi siswa dalam menyelesaiakan soal-soal tentang masalah kimia dengan mengikuti langkah-langkah Polya, yaitu: memahami masalah, merencanakan penyelesaian masalah, melaksanakan perencanaan, dan mengecek kembali proses.

\section{Pengelolaan Pembelajaran oleh Guru}

Berdasarkan hasil pengamatan pengelolaan pembelajaran oleh guru, terdapat lima langkah dengan 20 aspek yang diamati selama dua siklus (enam kali pertemuan). Kelima langkah yang diamati, terdiri atas pendahuluan, kegiatan inti, penutup, kemampuan mengelola waktu, dan pengamatan suasan kelas. Hasil pengamatan terhadap kemampuan guru mengelola pembelajaran adalah 3,70 (kategori sangat baik). Sebagian aspek dapat terlaksana dengan baik dan sangat baik.

Langkah pertama, yaitu pendahuluan terdapat tiga aspek yang diamati. Pertama menginformasikan tujuan pembelajaran.Aspek ini dilaksanakan mulai pertemuan pertama siklus pertama sampai pertemuan keempat siklus kedua.Sekala penilaian terhadap aspek ini sangat baik.Aspek kedua kemampuan memotivasi siswa.aspek ini juga terlaksana dengan baik selama enam kali pertemuan. Aspek yang ketiga, yaknik menghubungkan pelajaran saat itu dengan pelajaran sebelumnya atau membahas PR. Skala penilaiannya untuk pertemuan pertama, kedua, ketiga, keempat, baik.Sementara pertemuan kelima dan keenam, skala penilaiannya sangat baik.

Langkah kedua, yaitu kegiatan inti terdapat 12 aspek. Aspek pertama, yaitu menjelaskan materi yang mendukung tugas yang akan diselesaikan oleh siswa. Skala penilaiannya pertemuan pertama, kedua, dan keenam baik.Sementara pertemuan ketiga, keempat, kelima, skala penilainnya sangat baik.

Aspek yang kedua, yaitu menyiapkan situasi yang sesuai dengan materi pelajaran.Skala penialainnya pertemuan pertama dan kedua baik.Sementara pertemuan ketiga, keempat, kelima, keenam, skala penilaiannya sangat baik.Aspek yang ketiga mengarahkan siswa untuk memahami masalah.Skala penilainnya semuanya sangat baik.Aspek yang keempat, yakni meminta kepada siswa secara bergiliran untuk memecahkan masalah.Skala penilaian pertemuan pertama, kedua, ketiga, keempat, dan keenam baik, sementara pertemuan kelima, skala penilaiannya sangat baik.Aspek kelima, yakni mengoptimalkan interaksi siswa dalam memecahkan masalah.Pertemuan kelima dan ketujuh skala penilaiannya baik.Sedangkan pertemuan pertama, kedua, ketiga, keempat, keenam skala penilaiannya sangat baik. Aspek keenam, yakni mengamati cara siswa dalam memecahkan masalah. Pertemuan kelima skala peneliannya baik.Sementara pertemuan pertama, kedua, ketiga, keempat, keenam, skala penilaiannya sangat baik.Aspek ketujuh, yakni memberi bantuan 
Peningkatan Kemampuan Pemecahan Masalah Melalui Model Pembelajaran Berbasis Masalah pada Siswa Kelas XI-IPA SMAN I Sinjai Tengah (Materi Pokok Laju Reaksi)

kepada siswa yang mengalami kesulitan dalam memecahkan masalah.Pertemuan pertama dan keempat skala penilaiannya baik.Sedangkan pertemuan kedua, ketiga, kelima, keenam, skala penilaiannya sangat baik.Aspek kedelapan, yakni mendorong siswa untuk membandingkan jawabannya dengan jawaban teman.Pertemuan pertama, kedua, ketiga, dan kelima skala penilaiannya baik.Sementara pertemuan keempat, keenam, skala penilaiannya sangat baik.Aspek kesembilan, yakni mendorong siswa untuk tampil menuliskan jawaban dan menjelaskan dengan temannya.Pertemuan pertama, kedua, ketiga, dan keempat skala penilaiannya baik.Sementara pertemuan kelima, keenam, skala penilaiannya sangat baik.Aspek kesepuluh, yakni member pujian kepada siswa.Skala penilaian semua aspek sangat baik. Aspek kesebelas, yakni member umpan bali. Hanya pertemuan ketiga skala penilaiannya baik.Sementara pertemuan pertama, kedua, keempat, kelima, dan keenam, skala penilaiannya sangat baik.Aspek yang terakhir atau yang kedua belas, yakni member motivasi kepada siswa untuk tetap bersemangat dalam menyelesaikan tugasnya.Pertemuan kedua dan keempat skala penilaiannya baik. Sementara pertemuan pertama, ketiga, keempat, kelima, keenam, skala penilaiannya sangat baik.

Langkah ketiga adalah penutup.Terdapat dua aspek pada langkah ketiga.Aspek pertama adalah kemampuan menegaskan hal-hal penting berkaitan dengan
pembelajaran.Pertemuan pertama, kedua, ketiga, dan keenam skala penilaiannya baik.Sementara pertemuan keempat, dan kelima, skala penilaiannya sangat baik.Aspek yang kedua adalah menyampaikan materi berikutnya/memberika PR. Skala penilaiannya semuanya baik.

Langkah keempat, kemampuan guru mengelola waktu dalam pembelajaran, pertemuan pertama, kedua, ketiga, keempat, dan kelima skala penilaiannya baik, sementara pertemuan keenam, skala penilaiannya sangat baik.

Langkah yang kelima atau yang terakhir adalah pengamatan suasana kelas.Ada dua aspek dalam langkah kelima.Pertama aspek antusiasme siswa.Pertemuan pertama, kedua, ketiga, keempat, dan kelima skala penilaiannya baik.Sementara pertemuan keenam, skala penilaiannya sangat baik.

Berdasarkan hasil pengamatan kemampuan guru dalam mengelola pembelajaran mencapai nilai rata-rata 3,82.. Dengan demikian, dapat dinyatakan bahwa kemampuan guru dalam mengelola pembelajaran dalam penelitian ini memenuhi kriteria efektif (terlaksana dengan baik).

\section{KESIMPULAN DAN SARAN}

\section{A. Kesimpulan}

Berdasarkan uraian hasil dan pembahasan penelitian tindakan kelas selama dua siklus dengan 6 kali pertemuan pada pembelajaran kimia dengan model pembelajaran berbasis masalah terhadap siswa kelas XI-IPA UPT SMAN 7 Sinjai, maka ditarik beberapa kesimpulan sebagai berikut. 
1. Terjadi peningkatan aktivitas belajar kimia siswa melalui penerapan model pembelajaran berbasis masalah. Pada siklus I aktivitas positif siswa sebasar $42,04 \%$ dan siklus II $47,40 \%$ atau mengalami peningkatan $5,36 \%$.

2. Kemampuan guru dalam mengelola pembelajaran dengan menerapkan pembelajaran berbasis masalah pada setiap pertemuan berada pada kategori "baik", dan "sangat baik", sehungga kemampuan guru dalam mengelola pembelajaran dikatakan "efektif".

3.Kemampuan pemecahan masalah siswa mengalamai peningkatan setelah diterapkan pembelajaran berbasis masalah dimana nilai ratarata kemampuan pemecahan masalah pada siklus pertama $79,76 \%$ dengan ketuntasan klasikal $78,79 \%$ dari 33 siswa meningkat pada siklus kedua dengan nilai ratarata kemampuan pemecahan masalah 80,90 dengan ketuntasan klasikal 96,96\% dari 33 siswa yang mengikuti tes kemampuan pemecahan masalah siklus kedua.

4.Respon siswa terhadap proses pelaksanaan pembelajaran berbasis masalah cenderung positif yaitu rata-rata $92,42 \%$ (kriteria lebih dari $80 \%$ ).

5. Indikator keberhasilan tindakan yang diterapkan dalam penelitian ini mencapai target yaitu $96,96 \%$ ketuntasan klasikal dan 78,79\% ketuntasan minimum (ketuntasan klsikal $85 \%$ dan nilai KKM 70)

6. Untuk meningkatkan kemampuan pemecahan masalah dengan menerapkan model pembelajaran berbasis masalah, maka hal-hal yang perlu diperhatikan adalah (1) pembimbingan secara merata terhadap siswa yang mengalami kesulitan belajar, (2) pemberian motivasi yang tinggi terhadap seluruh siswa.

\section{B. Saran}

1. Kiranya pendekatan pemecahan masalah dapat digunakan oleh guru lain saat proses belajar mengajar berlangsung, sehingga siswa dapat lebih mudah mengerti, dan menganggap bahwa pembelajaran yang akan dihadapi bukan pembelajaran yang menakutkan.

2. Dengan menggunakan beberapa metode atau pendekatan mengajar sehingga proses belajar mengajar di kelas dapat dilakukan secara bervariasi sesuai dengan materi yang diberikan agar siswa tidak merasa bosan belajar dan mudah memahami materi pelajaran. Selain itu juga sebagai motivasi untuk memperhatikan apa yang diajarkan oleg guru.

3. Mengingat pelaksanaan penelitian ini baru berjalan dua siklus, maka peneliti atau guru lain diharapkan dapat melanjutkan dengan penelitian yang relevan dengan siklus yang lebih banyak untuk mendapatkan temuan yang lebih signifikan.

4. Penelitian ini dapat dilanjutkan oleh peneliti lain yang berminat dengan mengambil subyek yang cukup besar, sehingga perbedaan perlakuan yang diberikan dapat memberikan hasil yang lebih baik dengan ruang lingkup yang lebih luas. 


\section{DAFTAR PUSTAKA}

Amri,S, 2010,

Pengambangan

Pengaruhnya

Praktik Kurikulum.

Jakarta: Prestasi Pustaka.

Anonim, 2006. Panduan Penyusunan

Kurikulum Tingkat Satuan

Pendidikan Jenjang Pendidikan

Dasar dan Menengah. Jakarta:

Badan Standar Nasional

Pendidikan.

Peraturan Menteri Pendidikan Nasional RI No. 41 Tahun 2007, tentang Standar Proses untuk Satuan Pendidikan Dasar dan Menengah. Jakarta: Depdiknas.

Aqib, Z, Sujak. 2010. Panduan dan Aplikasi Pendidikan Karakter, Surabaya; Yrama Widya.

Arifin.Z, 2009. Evaluasi Pembelajaran. Bandung: Remaja Rosdakarya.

Arikunto. 2008. Penelitian Tindakan

Kelas, Jakarta: Bumi Aksara.

Aritonang, K,T. 2008. Minat dan Motivasi Dalam meningkatkan Hasil Belajar siswa. Jurnal Pendidkan Penabur (Online), Nomor 10/Tahun ke-7/Juni 2008 (http:/isjd.pdii.lipi.id/kurnal/710 081121.pdf, diakses 6 November 2012.

Asrori, 2007. Penelitian Tindakan Kelas, Bandung: Wacana Prima.

Budi, U. 2007. Kimia untuk SMA/MA Kelas XI. Surakarta: Pusat Pembukuan Departemen Pendidikan Nasional.
Benny. A, 2009, Model dan Desain Sistem Pembelajaran, Jakarta: Dian Rakyat.

Budiningsih, C.A. 2005. Belajar Dan Pembelajaran. Cet. Ke-1. Jakarta: Rineka Cipta.

Darmawan, 2010, Penggunaan Pembelajaran Berbasis Masalah dalam Meningkatkan Kemampuan Berpikir Kritis" Jurnal Penelitian Pendidikan. Vol 11 No.2, Universitas Pendidikan Indonesia 2011.

Dahar, R.W. 1991. Teori-Teori Belajar. Jakarta: Erlangga.

Djaali, 2009. Psikologi Pendidikan. Jakarta: Bumi Aksara.

Eveline. S. 2010. Teori Belajar dan Pembelajaran. Bogor: Graha Indonesia.

Ginting, A. 2008. Esensi Praktis Belajar dan Pembelajaran. Bandung: Humaniora

Goldberg, D. 2008. Teori dan Soal-soal Kimia untuk Pemula, Jakarta: Erlangga.

Hamalik, 2002. Pendidkan Guru Berdasarkan Pendekatan Kompetensi, Bandung: Bumi Aksara.

Kunandar, 2011. Langkah Mudah Penelitian Tindakan Kelas. Jakarta: Raja Grafindo Persada.

Kulsum, 2011. Implementasi Pendidikan Karakter Berbasis Paikem. Surabaya: Gema Pratama Pustaka. 